\title{
'There is no better means of instruction on China than letting China speak for herself': Thomas Percy and Hau Kiou Choaan
}

\author{
Mengmeng Yan* \\ Department of English Studies, Durham University \\ *Correspondence: mengmeng.yan@durham.ac.uk
}

Peer review: This article has been subject to a double blind peer review process

\section{(c) (1) $(0)$}

(c) Copyright: The Authors. This article is issued under the terms of the Creative Commons Attribution NonCommercial Share Alike License, which permits use and redistribution of the work provided that the original author and source are credited, the work is not used for commercial purposes and that any derivative works are made available under the same license terms.

\begin{abstract}
Hau Kiou Choaan (1761) represents a fresh enquiry into literary orientalism in Britain of the eighteenth century. This article will discuss Percy's adaptation of Hau Kiou Choaan from an original Chinese novel, and how the ways in which Percy interprets the Chinese novel signify his peculiar views of China. On the title page of Hau Kiou Choaan; or, The Pleasing History, Thomas Percy quotes from Jean-Baptiste Du Halde's A Description of the Empire of China and of Chinese Tartary (1738): 'There is no better means of instruction on China than letting China speak for herself'. It remains questionable, whether by presenting an original piece of Chinese literature, Percy has really let China 'speak for herself'; it is reasonable to argue that Hau Kiou Choaan carries as much information about China as it does about Percy's own perceptions of this country. Whether Percy's works and views of China provoked louder criticism or higher praise, his input into the studies of China was a positive one, for it contributed to an increasingly vigorous debate that would increasingly perceive differences as a source of strength, not weakness.
\end{abstract}

Keywords: Thomas Percy, Hau Kiou Choaan, reflection on China, editorial intention, translation, cross-cultural comparison

On the title page of Hau Kiou Choaan; or, The Pleasing History (1761), Thomas Percy quotes from Jean-Baptiste Du Halde's A Description of the Empire of China and of Chinese Tartary (1738): 'There is no better means of instruction on China than letting China speak for herself'. ' Du Halde's book on China is a well-known and much consulted text among European writers of China in the eighteenth century. ${ }^{i i}$ It is a collection of reports on different aspects of China, as well as a series of original Chinese sources, that were produced and recorded by various missionaries who had travelled to this country, most of them being the Jesuits. By quoting from Du Halde's work, Percy appears to be drawing attention to the 
uniqueness of his own work as a 'translation' from an authentic Chinese novel, at a time when the British public was still largely influenced by the cult of Chinoiserie and various fanciful accounts of the East. iii It remains questionable, whether by presenting an original piece of Chinese literature, Percy has really let China 'speak for herself'; it is reasonable to argue that Hau Kiou Choaan carries as much information about China as it does about Percy's own perceptions of this country. Percy's particular mode of mediation in producing Hau Kiou Choaan reflects tensions in Britain's encounter of Chinese literature at an early stage - a time when few British sinologists could read Chinese literature in its original language and British impressions of China still largely rested on its assumed otherness and backwardness. Percy's editorial interventions in Hau Kiou Choaan nonetheless facilitated the development of Sino-British cultural and literary encounters beyond a mere imaginary Western vision of the East that predominated Europe up until the eighteenth century.

Hau Kiou Choaan revolves around a complex plot about the pursuit of marriage. The motherless heroine of seventeen - Shuey-ping-sin - is the only child of a respected Chinese military officer who has been unjustly sent into exile due to a political conspiracy. The heroine's uncle, Shueyguwin, secretly longing to inherit his brother's large estate and property, plots to marry his niece who is now the keeper of her father's estate, in order to take sole charge of the family's wealth. Shuey-guwin then finds Kwo-khé-tzu, a young man from an influential family in the local area, and attempts to match him to his niece. Upon beholding the heroine from a distance (an opportunity devised by Shuey-guwin), Kwo-khé-tzu is bewitched by the beautiful Shuey-ping-sin and immediately decides to propose marriage to her. The heroine, however, is acquainted with the bad reputation of Kwo-khé-tzu and already sees through her uncle's plot. She manages to let her uncle marry his own ugly daughter, Ghiang-koo, to Kwo-khé-tzu instead, through a series of witty battles. Kwo-khé-tzu is furious upon discovery of the real bride after the wedding, and the rest of the novel sees him plot with various characters, including the heroine's uncle and the local officials, in an attempt to secure a union with the heroine.

The hero (Tieh-chung-u), son of a senior official of China, saves the heroine from being kidnapped by Kwo-khé-tzu (and thus from a forced marriage). Kwo-khé-tzu, angered by the hero's interruption of his plot, soon takes the opportunity to avenge the hero by secretly foodpoisoning him. This time, it is the heroine who promptly discovers the vile action taken against the hero, and she immediately brings the poisoned Tieh-chung-u back to her house to be looked after. While the hero and the heroine gradually become attracted to each other, they take care not to breach the social codes that expect a single man and a 
single woman behave formally unless they are officially engaged. Despite their precautions, rumours spread about the relationship between the hero and the heroine, and the heroine is criticised for taking the hero to her own house against social conventions for unmarried ladies. While Kwo-khé-tzu continues in his pursuit of the heroine, the heroine always manages to see through his trap and therefore saves herself from marrying him. The novel ends with the marriage of the hero and the heroine, a union of mutual respect and admiration. The union is also both approved of by their parents (the heroine's father is cleared of the charges and comes home), and is sanctioned by the emperor, who proves that the couple has remained chaste until their marriage.

Published at a time of the rise and development of the novel in Britain, Hau Kiou Choaan - which means 'a story of a happy union' in Chinese bears some resemblance to the conventional plotline of virtue finding its due reward in the British sentimental fiction in the eighteenth century (Fan, 1946: 117-125). ${ }^{\text {iv }}$ In his Dedication to the Countess of Sussex in the opening of this novel, Percy describes Hau Kiou Choaan as 'a moral disquisition [...] at a time when this nation [England] swarms with fictitious narratives of the most licentious and immoral turn'. ${ }^{v}$ It is a work 'designed to countenance virtue and discourage vice', and shows 'what strict regard to virtue and decorum is paid by writers amongst the Chinese' (Dedication). Percy wrote at a time when the development of the novel in Britain generated ongoing debates on the genre's seriousness of form and meaning; for example, the over-sentimental mood and questionable tastes in some of the English novels were criticised particularly for their potential to lead young readers astray. Here in the Dedication, Percy appears to be adopting the conventional trope of interpreting a foreign culture as an instrument of observing problems lurking inside Britain. Immediately following his remarks on the Chinese works' moral values, Percy notes that 'the deplorable ignorance they [the Chinese writers] labor under of those sublime and noble truths, which we enjoy to so little purpose' (Dedication). This comment suggests that the nominal Christianity of the British people does not enable them to assume a greater position than the Chinese in terms of virtue and morality. As a bishop, Percy is here expressing some disillusionment about the role of Christianity in his country and about the success of the Christian message in his own time. Elsewhere in the novel, however, Percy clearly defends the superiority of British morality by seeking to undermine Chinese ethical values. For example, earlier in the novel, Percy attacks the Chinese author's portrayal of the heroine as 'a perfect exemplar of all virtue' in a footnote. Percy suggests that 
The Chinese morals, notwithstanding their boasted purity, evidently fall short of the Christian, since they know not how to inspire that open and ingenious simplicity, void of all guile, which more elevated principles of morality propose to our esteem and imitation (vol. I: 129).

In this instance, Percy places Christian morals above Chinese morals by suggesting that only the former is pure and genuine. Percy's preface to this novel and his extensive notes in the text will demonstrate that the author (or the 'editor' as Percy would rather describe himself) does not perceive the writings of the Chinese as a means to regenerate or energize the literary culture of Britain, which he seems to imply in his letter of Dedication. vi

Upon the publication of Hau Kiou Choaan in 1761, the British public did not readily accept the novel's claim as an authentic piece of Chinese literature as, perhaps, hoped for by Percy. In the opening section of the preface to this novel, Percy describes how he acquired the manuscript of the Chinese novel in translation: the manuscript was found among papers of a gentleman who had resided in China and translated the novel from Chinese to English (and Portuguese) - presumably as a form of language practice. vii However, Percy's lengthy description about the origin of the manuscript failed to satisfy at least some of the readers. T. C. Fan points out that immediately after the novel was published, doubt was raised about its authenticity. Percy, disturbed, inquired about the novel in China through the East India Company, and inserted the 'Extract of a Letter from Canton' to prove the authenticity of the Chinese novel at the end of the second edition of his Reliques of Ancient English Poetry (1767); however, this letter was immediately pronounced as a forgery. Moreover, when questions were cast upon the incompleteness of information that Percy has provided in the preface to the novel, such as the absence of the name of the 'gentleman' among whose documents the manuscript was obtained, Percy seemed to have looked into the problem, and, in the Advertisement to a re-issue of Hau Kiou Choaan in 1774, Percy identifies the owner of the manuscript as 'Mr. James Wilkinson, an English merchant, equally respected for his ability and his probity' (Fan, 1946: 117). ${ }^{\text {viii }}$ By emphasising the 'ability' and 'probity' of the owner and translator of the manuscript, Percy seems eager to reassure the reader of the authenticity of the Chinese novel.

It is important that Hau Kiou Choaan is a work that comes from China, for this makes the work fundamentally different from imaginary and fictitious writings on China (or the East in general) that were already familiar to eighteenth-century British readers. In 'Thomas Percy and the forging of Romantic China', Peter Kitson argues that 
Percy's text [...] is not simply an imaginative recreation of China, a work of fashionable literary chinoiserie, nor another satirical depiction of Britain employing a bemused Chinese foil, but rather a serious, if flawed, attempt to translate and understand China, the pioneering project of a nascent British Romantic Sinology.

(Kitson, 2013: 27)

Percy's laborious efforts in his investigation into the source of the manuscript reinforce the significance of the work's credibility. The authenticity of the Chinese text creates fresh space for the development and studies of Sino-British encounters in the eighteenth century.

There remains no problem now that Hau Kiou Choaan is indeed a translation from a Chinese novel of the Chinese Qing Dynasty. ${ }^{\text {ix }}$ The doubts raised about the novel's authenticity in the eighteenth century might have been partly influenced by the age's production of some bestknown 'forged works' of British authors who claim their sources are rooted in ancient times, such as Chatterton's Rowley Poems and Macpherson's Ossian (Fan, 1946: 119; Kitson, 2013: 33). Moreover, the forging of Chinese culture in eighteenth-century Britain had already been prevalent by the time Hau Kiou Choaan was published, such as the artificial pagodas built in many English gardens, or the sixty-eight dramas about China that were presented on the European stage in this century (among which only one was authentically Chinese), or Josiah Wedgewood's English-made Chinese porcelains. ${ }^{x}$

Indeed, Percy's Reliques of Ancient English poetry (1765), a very influential work of his time, was accused of forgery. While Percy claimed that he rescued the original folio manuscript of the old songs and ballads in 1753 , his contemporary Joseph Ritson suggested that the manuscript did not exist at all (Palmer, 2004). In his own published works, Ritson suggests that the 'learned collector [Percy] has preferred his ingenuity to his fidelity', and criticises Percy for scarcely printing 'a single poem [...] fairly or honestly' and for practising 'every kind of forgery and imposture' (J. Ritson, 1792: xix-xxi; Ritson, cited in Palmer, 2004).In his short biography of Percy, Roy Palmer observes that Ritson's criticisms had been broadly justified when the folio manuscript was published in 18678 , and had been similarly endorsed by most scholars since then (Palmer, 2004).Although the Reliques was published after Hau Kiou Choaan, and Hau Kiou Choaan is not a forgery, Percy's peculiar approaches to sources and manuscripts can shape a reader's response to his editorial intentions and his own ideas on the subject matters of his texts.

Missionaries and merchants were two major groups of people from Europe who travelled to China in the seventeenth and eighteenth centuries. Prior to the publication of Hau Kiou Choaan, translations of 
Chinese books already existed, and yet all of them were made by missionaries (especially the Jesuits). ${ }^{\mathrm{xi}}$ Thus it was reasonable to cast doubt upon the first work of translation that claimed to be made from an English merchant.

In 1829, British Sinologist John Francis Davis provided a new translation of Hau Kiou Choaan and called it Fortunate Union. In his preface to Fortunate Union, Davis describes Percy's work as 'little better than a copious abstract' of the Chinese original (John Francis Davis, 1829, vol. I: viii). However, although Davis observes that in Percy's edition of the novel 'much was mistranslated, much interpolated, and a great deal omitted altogether', he readily recognises the merit of Percy's labours: 'he most ably edited, and very correctly illustrated (except where his version misled him) what certainly was, at the time when it appeared, by far the best picture of Chinese manners and society that we possessed' (Davis, 1829, vol. I: x). It is, however, hard to judge whether the flaws in the language are solely due to the limited knowledge of the translator (Mr James Wilkinson), as Percy admits he makes further omissions from the manuscript in his preface to the novel. ${ }^{\mathrm{xii}}$

Despite approaches that were meant to familiarise China to Britain, China was still a foreign and unreachable place for the majority of people in Britain in this period; the space between perceived understandings and concrete knowledge of China facilitated the increasingly vigorous explorations into this country and its literature and culture. Indeed, while learnings about China in Britain have gradually developed in strength and depth, Chinese scholars have also discovered fresh aspects of their own literature and culture through the ways in which such knowledge appealed to the foreigners. For example, although the Chinese original of Hau Kiou Choaan was believed to be a well-known work in China in the eighteenth century, it has not been a particularly widely read book

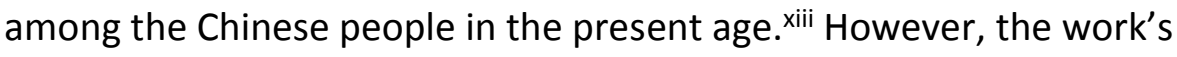
reputation of 'one of the ten masterpieces of prose fiction' in Europe during the eighteenth and nineteenth centuries has both drawn attention from scholarship on China and contributed to the continuous interest in the Chinese original. In his article, Fan also describes that 'whatever interest modern Chinese scholars have in the work is barely kept alive by the existence of foreign versions, of which Percy's was the first' ${ }^{\text {xiv }}$ While Fan might have gone a bit too far in suggesting that Chinese scholarship on Hau Kiou Choaan was solely driven by the text's popularity in Europe, the close relation between the novel's original and foreign versions reflects the mutuality of cultural influences.

In his preface to Hau Kiou Choaan, Percy frankly claims that the Chinese text and literary works of his own culture are nothing alike: 'examined by 
the laws of European criticism, he [the Editor] believes it [Hau Kiou Choaan] liable to many objections' (Vol. I, p. xii). Among the many flaws in this Chinese novel listed by Percy are the imagery that is 'often neither exact nor lively', the narrative that is 'frequently dry and tedious', and the taste that shows 'a littleness and poverty of genius' (Vol. I, p. xii). Moreover, Percy moves on from commenting on Hau Kiou Choaan to expressing his views on the Chinese at large. He argues that the 'littleness and poverty of genius' are present in 'almost all the works of taste of the Chinese', and inserts a footnote here to claim that 'perhaps their taste in gardening ought to be excepted' (vol. I: xii). The careful insertion carries a satirical tone, as it emphasises the lack of value in the Chinese taste rather than the presence of it. In the same paragraph, Percy accounts for the poverty of genius in the Chinese to 'that servile submission, and dread of novelty, which inslaves [their] minds' (Vol. I, p. xiii). In a work that is characterised by Percy's lengthy notes which work as explanations for Chinese customs and culture throughout the main text as well as in the preface, it is surprising to find that Percy does not provide reasons here for his accounts of the characters of the Chinese. Having consulted twenty-six books about China as references for his notes in Hau Kiou Choaan, Percy would have provided the sources of his claim if he had it. ${ }^{\mathrm{xv}}$ Unfounded claims such as this are also present in Percy's notes on the main text of this novel, most of which suggest not only the cultural differences between China and Britain, but also the inferiority of Chinese cultural prestige.

Nonetheless, in his preface, Percy readily points out that Hau Kiou Choaan is a more truthful account of the East than most works written on the East available in Britain of the period:

For it must be allowed to our present work, that the conduct of the story is more regular and artful than is generally seen in the compositions of the East; hath less of the marvelous and more of the probable. It contains an unity of design or fable, and the incidents all tend to one end, in a regular natural manner, with little interruption or incoherence. (vol. I: xiv)

Moreover, Percy observes that Chinese writers 'pay a greater regard to truth and nature in their fictitious narratives, than any other of the Asiatics' (vol. I: xiv). Just like his serious efforts to convince the reader that the novel is authentically Chinese, Percy sees the value of this work in its probability and naturalness, in contrast to the illusions and fantasies that are often associated with eighteenth-century eastern tales. While the editor appreciates little of this novel's literary qualities, he acknowledges the uniqueness of the work's subject matter in its probable account of the lives of the Chinese people. In Percy's own 
words, he offers Hau Kiou Choaan 'not as a piece to be admired for the beauties of its composition, but as a curious specimen of Chinese literature' (vol. I: xiv).

The preface shows some inconsistencies in Percy's editorial intentions. On the one hand, Percy appears to be adopting a neutral standpoint with regard to the reception of the novel as a literary work, as he suggests that 'the Editor is not concerned about the judgment that will be passed on this performance [...] and leaves to the critics to decide its merit'. On the other hand, his references to China in the preface have a tendency to focus on passive elements. Percy not only lists a number of flaws that he has found in this novel and relates them to the poverty of genius and taste in the Chinese writers (as it has been discussed previously in this article), but also stresses that he will not attempt to 'conceal nor exterminate' such faults in this work (vol. I, pp. xiv - xv). There are also other forms of inconsistencies in Percy's accounts of China, such as his summaries of the 'bright' and 'dark' sides of the Chinese in the index of Hau Kiou Choaan (vol. IV, Index). There are two headings under 'Chinese': 'the dark side of their character' and 'the bright side of their character'. Examples from the first category include 'corrupt', 'insincere' and 'greedy of gain'; and examples from the second category include 'decent, industrious and modest'. Some of the listed qualities appear contradictory to each other; for example, it is hard to imagine decent and modest people proud and crafty. Percy's use of an index in a novel presents this work more like a study book than a story, but this seems exactly what he would like it to be.

Fan attributes Percy's inconsistency to the two very different types of accounts of China in seventeenth- and eighteenth-century-Europe. The missionaries tended to describe the brighter sides of the country due to their greater knowledge and interest in the wisdoms of Chinese language and literature, whereas the merchants were more inclined to portray the country from less optimistic perspectives, since most of them only met the people of their own social classes in China, and their trading experience was not always happy. Fan argues that '[Percy] read all [sources from both sides], or almost all, but approved of few', but he also observes that Percy 'was forever balancing between the two sides of the Chinese character, and so falling into impertinent digressions and an apparent inconsistency' (Fan, 1946: 125).Fan's argument is also discussed by Kitson in his study of the text. Kitson chooses to focus on Percy's 'more negative comments [of China]' (thus the more fresh comments for eighteenth-century British readers), as he views Percy's Chinese writing as 'the anticipator of a new Romantic Sinology' that increasingly deviates from the canonical sinology set by the Jesuits (Kitson, 2013: 37). It is likely to be true, given Percy's extensive readings about China while he 
was producing the notes for Hau Kiou Choaan, that Percy read as many sources on China as he could possibly find in his time; however, whether he was consciously balancing between the different views of China shown in those sources is open to question. There is little sign in his writing that Percy feels perplexed while incorporating what he has read into Hau Kiou Choaan, and the way he uses the notes in this text shows how readily he shapes the sources in conveying his own ideas.

In his preface to The Citizen of the World (1762), Oliver Goldsmith (a close friend of Percy) describes what is perhaps the most important motif in his own work: 'the truth is, the Chinese and we are pretty much alike. Different degrees of refinement, and not of distance, mark the distinctions among mankind' (Oliver Goldsmith, 1762, vol. I: ii). ${ }^{\text {xvi }}$ In his preface to Hau Kiou Choaan, Percy has written something that can be treated as a counterpart to Goldsmith's claim: 'The manners and customs of the Chinese, their peculiar ways of thinking, and modes of expression are so remote from our own' (vol. I: xxiv-xxv, italics added). The contrast between the two authors' approaches to the Chinese theme clearly reveals Percy's unwillingness to seek identification between cultures. In Ros Ballaster's words, Percy's treatment of the novel's Chinese milieu sought more 'to promote estrangement rather than identification' (Ballster, 2005: 238). It is hard to tell if Percy really engages with the literatures of China while editing Hau Kiou Choaan, perhaps the Chinese novel remains for him 'a curious specimen' - a mere phenomenon to be commented on (Preface, vol. I: xiv).

In the preface to this novel, Percy also provides a detailed account of how his notes function in the text. He suggests that '[the notes] might procure the book a second perusal', and assures the reader that 'they are extracted from the best and most authentic writers on the subject' (vol. I:xxvi). The essential role of the notes is also 'presented' on the title page of Hau Kiou Choaan: 'WITH NOTES' appears beneath the full title of the novel and is printed in the second biggest font size on that page. The extent of Percy's laborious industry in his composition of the notes can be perceived through the 'Additions and Corrections' that is appended to the end of each volume of the novel.

The first six chapters of Hau Kiou Choaan focus on introducing the novel's main characters. While each of the characters is being described, Percy provides extensive notes on a range of areas related to the Chinese, such as their family relations, belief and worship, and the Chinese names. For example, in a note on the name of the heroine's cousin, 'Ghiang-koo', Percy first explains that this name means 'sweet young woman' in Chinese, and then notes an observation made by Du Halde of Chinese names: 'no nation in the world abounds with more fantastical names 
than the Chinese' (vol. I:72). Percy concludes the note by claiming that '[Du Halde's observation] is a proof that they [the Chinese] have unmeaning and improper ones [names]' (vol. l:72). Looking into the reference to Du Halde's work provided by Percy in this note, the reader can read Du Halde's words in A Description of the Empire of China by themselves:

We may remark, by the bye, that there is no Nation in the World which abounds so much in odd Titles to their Books as the Chinese Nations: The Names they give to Countries, and to many other things, discover this Fantasticalness; not but that these Names frequently have a good Meaning included in them (Du Halde, 1738, vol. 2: 221).

It is not difficult to find that Du Halde and Percy actually hold different opinions on the 'fantastical' names of the Chinese. While Du Halde suggests that one may discover the 'fantasticalness' in the rich variety of names and explains that the names often carry 'a good Meaning', Percy affirms that the names of the Chinese are merely 'unmeaning and improper'.

In some other instances, Percy does not readily examine what he has to observe in the context of the plot. For example, in the episode where the newly-wed Kwo-khé-tzu and Ghiang-koo are about to rest on their wedding night, Percy provides in his notes a paragraph from the original manuscript that he chose not to include in his edition of the text due to its 'ridiculous[ness]'. This paragraph depicts the husband's words and actions as he gets in bed and approaches his wife: 'Kwo-khé-tzu then stretching out his hands to find his way to bed, said, "Ah! She is asleep: I will pull off my cloaths and go to sleep too' (vol. I: 116). The English translation here does not do justice to the Chinese original, which is not presented as a speech, nor is the tone of it as exaggerated and amusing as it appears to be in the English text. xvii However, since Percy would not have been able to read the Chinese version of the novel, we may analyse this note as it is. In this note, Percy points out that

[this paragraph] did not so much proceed from simplicity in the Author, as from an affectation of modesty. The Chinese are a very affected people, and all affectation leads to absurdity (vol. I: 116).

Percy does not give any references in this note. If one situates this episode in the context of the development of the story, the amusement of Kwo-khé-tzu's words can then be easily explained. Earlier in the novel, the reader is informed that Kwo-khé-tzu believes that he is going to marry the beautiful heroine, Shuey-ping-sin; however, the heroine wittily saves herself from a marriage forced by her uncle, and also manages to 
persuade her uncle to marry his own ugly daughter (Ghiang-koo) to Kwokhé-tzu instead. Kwo-khé-tzu does not realise that he has not married the beautiful bride on the wedding night, for Ghiang-koo has turned off the light on purpose to hide her face from her husband. Therefore, the amusing account of Kwo-khé-tzu's words and conduct in this episode is ironically charged, and it prepares the reader for his shocking discovery

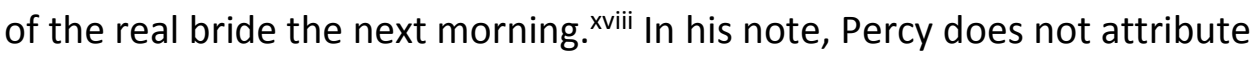
the seeming absurdity of this episode to the Chinese author of the novel, but chooses to define the characters of the Chinese people straightaway from what he willfully believes to be ample evidence.

Similarly, at the point when the hero, Tieh-chung-u, refuses to accept the suggestion of Shuey-ping-sin's uncle that he marry her, Percy writes in his footnote to this incident that 'where the women in general are held so cheap, we must not wonder that the men should be so backward to acknowledge a soft and respectful passion for any one of them' (vol. II, p. 129). Percy's footnote here is heavily misleading, which may be caused by his lack of understanding of the social and cultural realities of Chinese feudal society. Tieh-chung-u's refusal to marry the woman he admires at her uncle's suggestion should not be treated as a 'backward' action. In the context of the novel, Shuey-ping-sin has previously brought the poisoned Tieh-chung-u back to her own house to be looked after - an action in breach of restrictions to male-female relationships in feudal China. If he married her now, it would very possibly lead to suspicion that they had a sexual relationship that needs to be covered up by marriage. As a result, Tieh-chung-u has to protect the reputation of the heroine and manifest vigilance towards social conventions. In this footnote, Percy also asks the reader to 'bear the above remarks [about the 'cheapness' of Chinese women] in mind throughout this and some of the following chapters'. This note is particularly provocative as it attempts to influence the reader's understanding of the text through deliberate instruction (vol. II: 129).

Hau Kiou Choaan is a novel that highlights the heroine's extraordinary courage and perseverance to follow her own heart in love and marriage against patriarchal forces. The focus of this work is to exult Shuey-pingsin's strife to hold onto her rights both at home and in society. Shueyping-sin's exceptional intelligence and bravery are esteemed by most of the novel's male characters. For example, Che-bien, a local official who has once tried to find faults with the heroine but later becomes impressed with her wisdom and courage, speaks to Kwo-khé-tzu: 'you must not consider her [Shuey-ping-sin] [...] as a young woman of the ordinary stamp. Although she is very young, she hath uncommon abilities' (vol. III: 2-3). The English translation here does not do full justice to the extent of Che-bien's praise of the heroine; in the original Chinese 
version of the novel, Che-bien describes Shuey-ping-sin as a young lady with 'the wisdom and bearing of a historic hero'. ${ }^{\text {ix }}$ When Kwo-khé-tzu has secured an 'order of marriage' between him and Shuey-ping-sin from a local official through some underhand contrivance, the heroine goes to the court to redress her grievances. Her honest and forceful petition convinces the judge of the injustice she faced and saves herself from marrying Kwo-khé-tzu against her will. Court appeal for women was not common in eighteenth-century China, and in some geographical regions it was considered a disgrace that women should appear in person at court. On the one hand, the Chinese author of this novel idealises the condition of women's rights in society of the period; on the other hand, the author's consciousness of women's social limits in real life generates their (female) characters' aspiration to individual and political freedom. ${ }^{\mathrm{xx}}$ Moreover, when asked to give consent to Kwo-khé-tzu's offer of marriage to his daughter, Shuey-ping-sin's father gives his sole priority to the heroine's own inclinations, and declines the offer of marriage as well as an offer that Kwo-khé-tzu's father would help release him from exile should their children get married (vol. III: 123). Furthermore, after the hero and the heroine are married, the heroine's views and ideas have always been taken into consideration in family gatherings at her husband's household. xxi Indeed, Kwo-khé-tzu's fervent pursuit of Shueyping-sin is partially brought by his attraction to her uncommon abilities as a young woman. For instance, after the heroine's uncle tells Kwo-khé-tzu about the witty measures Shuey-ping-sin has undertaken to avoid marrying him, Kwo-khé-tzu tells her uncle:

When first I saw [Shuey-ping-sin], I fell in love with her for her beauty, but now were she more ugly than Ghiang-koo, I should admire her no less for her ingenuity and wit. I am distracted to obtain her: you must still contrive some way to oblige me (vol. I: 160-162).

Essentially, despite occasions in this novel where Shuey-guwin and Kwokhé-tzu selfishly dismiss the heroine's true feelings and attempt to force marriage on her, Hau Kiou Choaan is a typical novel of the Chinese fiction school of 'gifted scholars and talented ladies' that portray and exult women's pursuit of liberty and independence against social and cultural oppressions. ${ }^{\text {xii }}$ When Shuey-ping-sin is introduced to the reader at the opening of the novel, she is described as 'distinguished for the rare endowments of her mind, and greatness of her capacity, in which she equalled the most eminent of the opposite sex' (vol. I: 70). Shuey-guwin and Kwo-khé-tzu's loss against the heroine in a series of contests of wit can be seen as the novel's satire of patriarchal presumption. Percy's particular remark for the reader to keep in mind his remark on Chinese 
women's lowly position in society through the novel's portrayal of the heroine will increasingly prove incoherent to the theme and focus of the novel itself.

James Watt describes that a large number of Percy's notes 'offer digressive observations that seek to typify the national character [of the Chinese], often without any appeal to substantiating authorities' (Watt, 2007: 97). Du Halde's work is also consulted and referenced by Goldsmith in The Citizen of the World; however, the way Goldsmith uses this material demonstrates a more willing and faithful engagement with the sources. For example, in both Letter LLXXXII and Letter XCV in The Citizen of the World, Goldsmith provides references to Du Halde's texts on Chinese philosophical maxims in his footnotes, in order to better illustrate the philosophical messages carried in these letters.

Interestingly, Watt argues that Percy 'often sought to undermine what he referred to as the "boasted purity" of Chinese ethical maxims' (Watt, 2007: 98). While Goldsmith makes efforts to appeal to the value of Chinese ethical and philosophical beliefs, Percy seems to be more inclined to produce his own 'handbook of China'. ${ }^{\text {xiii }}$

In his 'Letter on Du Halde's History of China' (1738), Samuel Johnson observes that Du Halde's work can make the British reader notice more similarities between the Chinese and the British. Johnson describes that:

An attentive reader [...] will find a calm, peaceful satisfaction, when he reads the moral precepts, and wise instructions of the Chinese sages; he will find that virtue is in every place the same [...] he will enjoy all the pleasure that novelty can afford, when he becomes acquainted with the Chinese government and constitution; he will be amazed to find that there is a country where nobility and knowledge are the same, where men advance in rank as they advance in learning, and promotion is the effect of virtuous industry [...] He will read of emperors, who [...] have neither stored, nor threatened, nor kicked their ministers [...] but have, with a greatness of mind worthy of a Chinese monarch, brought their actions willingly to the test of reason, law, and morality'. (Johnson, 1738, The Gentleman's Magazine, vol. VIII: 365)

Johnson's comments on the Chinese emperors, in particular, portray a different picture from the traditional images of eastern despots that are common in eighteenth-century oriental tales. Essentially, Percy, Goldsmith and Johnson have all tried to portray China against various fanciful illusions that this country had long been made to associate with. While Johnson and Goldsmith seek to find common ground between British and Chinese cultures, Percy is inclined to interpret the other 
culture as both different and inferior. The authors' disparate responses to and use of the same text (i.e. Du Halde's A Description of the Empire of China) also demonstrate how source materials can be shaped and manipulated to accommodate the writers' own authorial intentions.

While some of Percy's friends saw more merit in the notes than in the main text of the novel, Hau Kiou Choaan did not seem to enjoy more success because of them. William Shenstone wrote to Percy after reading an advance copy of the novel, that 'Your Annotations have great merit' (Sep. 1761), and yet he was uncertain about the novel's success in the market. ${ }^{\text {xiv }}$ It turned out that the novel was a commercial failure and a reissue - which was prepared in 1774 - was never published. ${ }^{x x v}$ Percy's publisher, Robert Dodsley, wrote in a letter to Shenstone that he would 'never own' Hau Kiou Choaan; and the Critical Review (Nov. 1761) dismissed the novel as 'the most unpleasing performance which we have perused for some months past' (Nick Groom, 1999: 211, in Bertram H. Davis, 1989: 90). The lack of success for this novel might have been due to the content of the original Chinese plot, or Percy's heavy editorial intervention, or both. ${ }^{x v i}$ Yet credit needs to be given to Percy's indefatigable industry in his research for this work. Despite Percy's subjective comments, many of the notes adequately introduce knowledge about China in a wide range of areas, such as its government, customs, and beliefs. It is not the twenty-six books about China (and many of them are produced in multiple volumes) read by Percy that generated problems, it is the way Percy chooses to use them and develop his own argument upon them that provoked controversies.

Together with his Miscellaneous Pieces Relating to the Chinese (1762), Hau Kiou Choaan represents a fresh enquiry into literary orientalism in Britain of the eighteenth century. Watt describes Percy's writings about China in the 1760s as 'the stimuli that might rejuvenate British literary culture' (Watt, 2007: 95, italics added). Whether Percy's works and views of China provoked louder criticism or higher praise, his input into the studies of China was a positive one, for it contributed to an increasingly vigorous debate that would increasingly perceive differences as a source of strength, not weakness. 
'The quotation from Du Halde's work appears in French (the language it was originally published in) on the title page of Hau Kiou Choaan. The complete French quotation is as follows: 'Il n'y a pas de meilleur moyen de s'instruire de la Chine, que par la Chine même: car par la on est sûr de ne se point tromper, dans la connaissance du génie, et des usages de cette nation'.

ii The French title of this book is Description de la Chine et de la Tartarie Chinoise. An English edition of the book was published in 1738 in 2 volumes, entitled A Description of the Empire of China and of Chinese Tartary. Another English edition of the book was published in 1741 in 4 volumes, entitled The General History of China. Both English versions of the text are available at Eighteenth Century Collections Online.

iii Despite its claim as a 'translation', Hau Kiou Choaan contains a considerable amount of Percy's own notes that can shape the readers' understanding of the text.

iv Although Fan wrote this article in 1946, he is a special critic in the studies of China in English Literature. Fan is one of the earliest Chinese scholars who had undertaken research in the West on Sino-British literary encounters; he was capable of studying the Chinese texts both in their original language and in their translations, and thus was in a favourable position of drawing comprehensive cross-cultural comparisons. Fan's study has been an important reference for many of his successors.

$\checkmark$ 'Dedication to the Right Honorable the Countess of Sussex', Hau Kiou Choaan, 1761. All subsequent references to Hau Kiou Choaan will appear in-text.

vi In the preface to this novel, Percy refers to himself as 'the Editor' of this Chinese work.

vii The opening lines of the preface outline how the manuscript was first acquired by Percy: 'The following translation was found in manuscript, among the papers of a gentleman who had large concerns in the East-India Company, and occasionally resided much at Canton (the manuscript is dated 1719). It is believed by his relations, that he had bestowed considerable attention on the Chinese language, and that this translation (or at least part of it) was undertaken by him as a kind of exercise while he was studying it [...] it should seem to have been drawn up under the direction of a Chinese master or tutor'.

Percy also observes that the manuscript consists of 4 volumes: 'the three first [sic] of these volumes are in English: the fourth in Portuguese; and written in a different hand from the former. This part the Editor hath now translated into our own language'. However, Percy does not write in detail about the possible involvement of different translators in the original manuscript of the novel.

viii In his footnotes in this article, Fan mentions that L. F. Powell has collected the essential documents on the controversy over the manuscript of this novel (Powell, 'Hau Kiou Choaan', The Review of English Studies, 1926, II: 446-55). The re-issue of this novel was never published.

ix In a number of Chinese materials that I have consulted, Hau Kiou Choaan is often referred to as a novel of the Chinese Qing Dynasty (c.1644 - 1912). The exact year of publication is not mentioned in these materials. In his preface to Hau Kiou Choaan, Percy mentions that the manuscript is dated 1719; therefore, the original Chinese novel should have been published sometime between the second half of the seventeenth century and the early eighteenth century. 
${ }^{x}$ Information about the number of dramas about China performed in Europe in the eighteenth century is taken from Ward, 2010: 15.

xi Earlier translations of Chinese works include, for example, D' Entrecolles' translation of portions of Chin Ku Chi' Kwan in c.1650 and Joseph de Prémare's translation of The Little Orphan of the House of Chao prior to 1735. Translations of Chinese literary works are discussed by Fan, 1946: 118.

xii In the preface to the novel, Percy describes that 'Sometimes where the narrative was insupportably diffuse and languid, interrupted by short questions and answers of no consequence, or retarded by dull and unmeaning repetitions: in these cases he [the Editor] could not help somewhat shortening and contracting it' (vol. I: xxi-xxii).

xiii The Chinese original should have enjoyed a good reputation in China in the eighteenth century, for - as Percy rightly suggests - 'That book would naturally be put first into the hands of a foreigner, which is in highest repute among the natives' (Preface, vol. I: xi).

xiv Information about the novel's popularity in Europe is provided by Fan, 1946: 119.

${ }^{x v}$ Following the preface, Percy provides 'A LIST of books from whence the following Notes are extracted', vol. I: xxix-xxxi.

xvi Italics added. At first reading, The Citizen of the World might invite comparison with Montesquieu's The Persian Letters (1721) - both works adopt the epistolary structure and engage characters that travel in foreign countries; however, the emphasis in this article is firmly on representations of China.

xvii Original Chinese version of Hau Kiou Choaan (《好述传》), 2014: 206.

xviii Kwo-khé-tzu is portrayed as an idle and vulgar young man from a wealthy family; he works with the heroine's uncle in attempts to force the heroine marry him.

xix This is my own translation of the Chinese lines from the original text: “他虽是一个小 女子, 却有千古大英雄的智量' (Chinese version of Hau Kiou Choaan (《好速传》), 2014: 267).

${ }^{x x}$ The original Chinese version of Hau Kiou Choaan was published anonymously; in the book, the Chinese author only identifies themselves as 'a person from the school of Confucian ethics' (“名教中人”).

${ }^{x x i}$ For example, even after the heroine's marriage to the hero, Kwo-khé-tzu continues to create troubles for the couple. The heroine is invited to join the family meeting in her husband's household and discuss measures to defend against Kwo-khé-tzu's accusations (vol. IV: 107).

xxii The type of Chinese novel that Hau Kiou Choaan belongs to is called 'gifted scholars and talented ladies' when it is translated literally from Chinese to English. This kind of novel appeared in the Chinese Qing Dynasty $(1636$ - 1912) and is often made to associate with this dynasty by literary critics from later periods. It often involves romance and exults the hero and the heroine's uncommon wisdom and abilities against predominant feudal conventions. 
xxiii In so far as cultural encounter is being used in The Citizen of the World to explore values close to home (i.e. Britain), it might be argued that this work is not a book about China at all. However, in some fundamental ways - such as the setting of the work in the context of China, introduction of detailed Chinese traditions and customs, and the author's consultation of other studies of China - this work is certainly a book about China.

xxiv Shenstone wrote to Percy that he could 'form no Conjecture, what vogue [this novel] will obtain', in Cleanth Brooks (ed.), 1977: 114.

xxv Fan, 1946: 117; Watt, 2007: 101. Kitson notes that despite its commercial failure, Hau Kiou Choaan was an influential text of the period, for it was soon translated into French, German and Dutch in the late 1760s (Kitson, 2013: 34).

xxvi One may argue that the plotline and sentiments of the original Chinese novel are comparable, and even similar, to a range of British novels that were published in the same period, and thus Hau Kiou Choaan might have appeared to be less exotic and 'distinctive', and fallen below common British readers' exp Letter on Du Halde's History of China ectations of what an eastern fiction should look like (more fantastical and foreign, perhaps).

\section{References}

\section{Primary Sources (English)}

Brooks, Cleanth ed. (1977), The Correspondence of Thomas Percy and William Shenstone, New Haven: Yale University Press.

Davis, John Francis (1829), The Fortunate Union: a Romance, London: Oriental Translation Fund.

Du Halde, Jean Baptiste (1738), A Description of the Empire of China and of Chinese Tartary, London: T. Gardner, Eighteenth Century Collections Online, http://find.galegroup.com/ecco, accessed 30 June 2016.

- (1741), The General History of China, London: J. Watts, Eighteenth Century Collections Online, http://find.galegroup.com/ecco, accessed 30 June 2016.

Goldsmith, Oliver (1966), The Citizen of the World, Collected Works of Oliver Goldsmith (Volume II), ed. Arthur Friedman, Oxford: Clarendon Press.

Johnson, Samuel (1738), 'Letter on Du Halde's History of China', The Gentleman's Magazine, Vol. VIII, 365.

Percy, Thomas, Hau Kiou Choaan (1761), London: R. and J. Dodsley, Eighteenth Century Collections Online, http://find.galegroup.com/ecco, accessed 30 June 2016. 
- Miscellaneous Pieces Relating to the Chinese (1762), London: R. and J. Dodsley, Eighteenth Century Collections Online, http://find.galegroup.com/ecco, accessed 30 June 2016.

\section{Primary Sources (Chinese)}

Original Chinese version of Hau Kiou Choaan (《好述传》) (2014), Beijing: Huaxia Publishing House.

\section{Secondary Sources}

Ballaster, Ros (2005), Fabulous Orients: Fictions of the East in England 1662-1785, Oxford: Oxford University Press.

Davis, Bertram H. (1989), Thomas Percy: A Scholar-Cleric in the Age of Johnson, Philadelphia: University of Pennsylvania Press.

Fan, T. C. (1946), 'Percy's Hau Kiou Choaan', The Review of English Studies, 22 (86), 117-125.

Groom, Nick (1999), The Making of Percy's Reliques, Oxford: Clarendon Press.

Kitson, Peter (2013), Forging Romantic China: Sino-British Cultural Exchanges, 1760-1840, Cambridge: Cambridge University Press

Palmer, Roy (2004), 'Thomas Percy', Oxford Dictionary of National Biography, http://www.oxforddnb.com/view/article/21959?docPos=6, accessed 30 June 2016.

Porter, David (2013), The Chinese Taste in Eighteenth-Century England, Cambridge: Cambridge University Press.

Ward, Adrienne (2010), Pagodas in Play: China on the Eighteenth-Century Italian Opera Stage, Lewisburg, PA: Bucknell UP.

Watt, James (2007), 'Thomas Percy, China, and the Gothic', The Eighteenth Century, 48 (2), 95-109.

\section{To cite this article:}

Yan, M. (2016). 'There is no better means of instruction on China than letting China speak for herself': Thomas Percy and Hau Kiou Choaan. Exchanges: The Warwick Research Journal, 4(1), 68-85. Retrieved from: http://exchanges.warwick.ac.uk/index.php/exchanges/article/view/117 